\title{
Developing European Key Competences with Green Education
}

\author{
By Margherita Maria Sacco ${ }^{1}$, Elena Liliana Vitti ${ }^{1}$, Alberto Parola ${ }^{2}$
}

\begin{abstract}
Building\&Learning Project is action-research focused on the environmental consequences of technology. The didactic design is structured on the classic program proposed for the scholar discipline Technology for the first grade of secondary school; it tries to answer to the requirements of the National Plan for a Digital School (PNSD). Our first aim is to overcome the diktat "teach how to use the media" and reach the capacity to "teach with the media", to avoid the danger of a "technocentric illusion" and to get the purpose to develop the competences proposed by Europe and Italy. Our teacher-researcher prepared every lesson to help the students to: a) get the disciplinary aim; b) understand the process and the consequences that every technology brings with itself; c) apply the theory in a practice activity. Every lesson is divided in two phases: the theoretical part is based on the method of Cooperative Learning, while the second part is a practice activity where students build with LEGO Education Kit a model that forecasts the application of the theory. After the first period, we introduced also a Story-telling part because the students showed great difficulty in expressing the theory explained.
\end{abstract}

Keywords: European key competences - Media Education - Cooperative Learning - Sustainability education STEM

\section{Introduction}

Building\&Learning Project is an action-research on the introduction of the famous LEGO's bricks in the first grade of secondary school for the development of an environmental awareness through a critical knowledge about green and pollutant energy. In particular, we monitored the effectiveness of the inductive and deductive learning method for the development of European life skills. One of the sub-goals of the civic competence was the environmental awareness.

Competence in as an intrinsic individual feature randomly connected to an effective performance (Spencer and Spencer, 1995). This element is not something you can have, but you can be: is not an object of reality, there are competent people able to solve problems (Milani, 2013). To encourage the development of European competencies, school activities can't just focus on assignments' personalization of (Delors, 1996): the competence must be thought as cultural and scientific baggage, articulated around the ability of problematize the reality, make assumptions to solve problems and learn how to learn (Fioretti, 2010).

One of the social questions of education is the need to create an active citizenship and to support the students to became aware and responsible citizens, able to make and take decision realizing the principle of "government by everyone", making all the people 
potentially rulers, as required by authentic and open democracies (Porcarelli, 2016). To make this possible, every person must develop the ability to use the cognitive instruments to dominate emergencies, problems and debates and to make rational and reasoned choices, based on democratic and universally principles. To get this purpose, we designed a course using some principles of active and cooperative learning, considering that every situation and every classroom are different and that it is necessary to exchange part, or all, the activities during the process. For this reason, the èquipe choose to improve an action-research, which considers the "human factor" and the practice dimension as primary elements of the environment (Losito, Pozzo, 2005). This method is perfectly compatible with the aim of educational intervention because it does not exist just to observe the reality and report what happened in the context, but has the explicit purpose to change people's behavior and/or the surrounding context (Trinchero, 2002). It produces at the same time new theoretical information thanks to the systematic methods of observation and data collection. Reeves (2000) underlines that humans science should work on relevant social questions: researches should be designed to solve real problems and to produce new knowledge useful also for other practitioners. Our action-research tried to answer to the social question of a quality education for everyone. Hosting school Pacinotti ( Turin - Italy) is attended by multicultural classes, which is trying to work for the social integration of foreign minors (sometimes parentless) who don't speak Italian and children with deprived socio-cultural background. Besides, a relevant number of students with special educational needs attend this neighborhood school so we tried to design a method for the inclusion of every single student without the use compensatory instruments and dispensatory measures.

\section{Theoretical Bases of Building\&Learning Courses}

The first step of every educational intervention is to renounce to the illusion that the proposed activities, even with a perfect theoretical project, are able to change the reality by themselves. In educational context there is a phenomenon called magic thought, the attitude of the practitioner to believe that it is just necessary to replicate the design of another intervention, that worked in a different place, to get the same results. Unlucky, when a "good practice" or a new law is considered as a recipe or as a checklist to follow, the experiments bring to a flop and to drop out the desire of changing (D'Angella and Orsenigo, 1999). Research group works in the area of Media Education, where this phenomenon is called techno centrism. This element is the belief, or the hope, that digital technologies could have an intrinsic power to change for the better the reality (Ranieri, 2011). Media and digital technology are considered as instruments that mechanically can change and influence psychological and social students' world. This simplistic idea reduces in a deterministic vision the educational technology and its potential (Scarcelli, 2017). To over cross the technocentric illusion, Builduing\&Learning courses are designed using the principles of Media Education, which are not just about learning how to use the digital technology but is centered on the academic learning throughout the media. For example, our courses tried to overcome the diktat of teach using media in favor of teach with media, over crossing topic's traditional limits, increasing and improving student experiences and competences (Parola et al, 2019, p. 4). Teachers and 
the researchers must not confuse the meaning with the goal: media and digital technologies are just teaching mediation instruments, objects useful to reach the goals as, traditionally, the school did with the textbooks. School cannot represent a social context totally separated from the real life understood as a place where learn lessons. It should be a miniature social group where studying and self-improvement are part of a collective and current experience (Dewey, 1965). For that reason, teachers should renounce to rigid scholar programs and bring the focus on the "learning energy", helping the students to became able to act with a growing autonomy, judgment capacity and personal responsibility (Guasti, 2016). According to Trinchero (2012), every school should answers to four key-challenges: 1) helping students using scholar knowledge, promoting not the accumulation of passive information, but the development of an action-thought; 2) establishing synergy between scholar topics and real life; 3) promoting not-formal and informal knowledge as cure for demotivation and early school leaving; 4) connecting the idea of school knowledge to the future of the students and stimulating the building of a life-project.

To project didactic activities for the development of the European competences, it is necessary to avoid traditional wall-teaching method, which sharply divide between scholar knowledge and student's life, and to propose a bridge-teaching, which is aimed at students' "vital world" (Castoldi, 2011, in Porcarelli, 2016). The first step to pass from a wallteaching to a bridge-teaching method, is to accept that a rigid project is basically useless. The program must be changed when the surrounding context requires something different from the original idea (Porcarelli, 2016). The project should be a limitless and timeless work-in-progress that change with the context. A constant monitoring of the situation gives information about the needed change. To over cross the simply knowledge limit and get to the competence, teachers should propose situated problems, to sustain the building of operative representation of problematic situation (Maccario, 2012). Situated problem are the elaboration of functional representation of complex situations or tasks that require to connect several information before choosing and action. The activities should be able to stimulate the curiosity of the students, the desire to personally research, discovering and constructing knowledge, understood as an element constantly changing with new experiences, gained through an experimental verification and the problematization of the notions, connecting as possible knowledge and experience, common conscience, popular knowledge and formal knowledge (Cambi, 2014). A good way to project situated problems is to follow some principles of Flipped Classroom method, that turns round traditional teaching framework: students study the theory at home, while the school time are to solve real problems connected to the curricular knowledge (Eaton, 2017). Usually in a Flipped Classroom teacher asks to the students to analyze some theoretical concepts at home to dedicate the school time to practice exercise and study. This choose is possible just if every student has a PC at home and if no one arrives at school without the required knowledge. To over cross these problems we deleted the homework part and projected activities with theoretical and experimental parts. The most relevant element of Flipped Classroom method is the Socratic structure of the knowledge building, based on dialogue and personal reasoning. Interest and curiosity about encountered problems can motive the students to get involved and find solutions, interpretations and explanations learning by personal experience. The Flipped Classroom 
method allows to follow Montessori's principle of "help them doing by themselves". The explanation of theoretical topics after a practical exercise avoids a mechanical study and memorization without understanding and interesting. This methodology keeps the focus on the connection between scholar knowledge and natural human needs, promoting and sustaining personal motivation and interest. XXI century teachers should over cross the traditional lesson structure and try to propose deductive and inductive learning methods. The first one proceeds from general to particular, exposing a principle or a law and verifying his applicability to the specific case. The second one totally follows the scientific method rules: starting from the observation of a particular fact, teachers sustain personal formulation of hypothesis to find the general law. This proceeding makes possible learning based on the discover of knowledge through the problematization of scholar topics. Usually, the flipped lesson has three different phases (Cecchinato and Papa 2016):

Throw the challenge: teacher activates students' interest, curiosity and knowledge desire about the proposed topics, passing from the enunciation of arguments to a doubtful and hypothetical form.

Lead the challenge: students should act as real scientist, proceeding by trial and error, autonomously discovering the processes of academic theory and scholar knowledge. Method's aim is to promote the development of a scientific attitude through a practice research exercitation, sustaining the value of the doubts instead that an uncritical assimilation of information. This second ends with the production of documents and material by students.

Close the challenge: every lesson ends with a moment of revision and evaluation. A collective reflection and confront about the theoretical topics can clarify, make explicit and consolidate the new knowledge, starting from the analysis of the material produced by students during the second phase.

Cecchinato and Papa suggest using team working and peer education, so the students have the possibility to learn with the interaction and confront between people with different ideas. Through the reconstruction and verbalization of the personal Learning process, students can develop metacognitive ability and reinforce the ability of reflection and expression. Kaneklin (2010) claims that the group represents a concrete experiential environment where people can find a confront term and a reference point, as the values that can influence life chooses. Additionally, through the groups it is easier interfere with attitudes and behaviors of the participants in team working situation rather than keeping the focus on single persons. Interventions on the group and its rules make easier win against personal resistance and create a spontaneous involvement, a high level of social comparison and a greater consolidation of personal decisions. Kröninger-Jungaberle et al (2014) underline also that the cooperative learning can help the students to feel not as passive "objects of an intervention" but as "agents of their own development", because this method supports students to discover their own and others' resources and ability. Johnson et al (2015) argue that peer education is particularly important to get three goals in an educative context: 1) the scholar results, that became less centered on simple memorization of information and most guided by a personal motivation and by a critical reasoning; 2) the relationship between students, reinforced by the mutual support; 3) the psychological wellbeing, increased by the development of a self-efficacy sense, a growing 
confidence and self-idea, elements that help to face without stress the obstacles. Lastly, most of the ex-peer gained consolidated competences and abilities potentially spendable in the real life (Ottolini and Rivoltella, 2014). Nevertheless, to realize a cooperative learning activity it is necessary to create some specific conditions: a positive interdependence, an individual and collective responsibility sense, a constructive and direct interaction, social abilities, evaluation of team working. To propose a cooperative learning approach, every teacher should: 1) preliminary establish the goals, the groups' dimension and composition, the role of every student; 2) explain clearly the cooperative approach and the specific task, highlighting the criteria to catch the goals and the behaviors accepted or not during the lessons; 3) monitor learning level of every group and intervene, if necessary, to improve the team working and the chance to get the aims; 4) verify and evaluate the quantity and quality of results and be sure that every student becomes able to monitor personal and group work through the promotion of confrontations about improvement possibility (Johnson et al. 2015).

\section{Practical Application}

Builduing\&Learning project is structured in order to achieve the goal of expanding knowledge, abilities and competences of the students, using a didactic method composed by 4 steps (Fig. 1):

Step 1 - Know: a short conceptual introduction, lasting about 15-20 minutes, of the subject matter in order to allow familiarisation with knowledge needed for subsequent activities.

Step 2 - Predict: the students, through guiding questions, develop a theory/hypothesis.

Step 3 - Observe and record: testing phase, during which pupils plan and execute experiments apt to verify or confute their hypothesis.

Step 4 - Deduce: students validate their theory analysing results of the experiments and formulate new scientific rules.

Knowledge

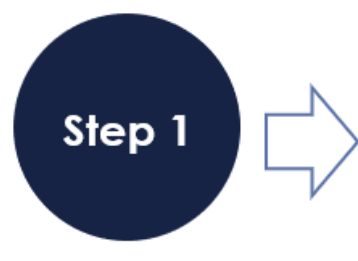

KNOW

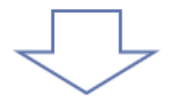

Conceptual introduction

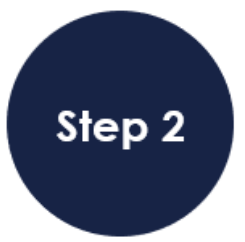

PREDICT

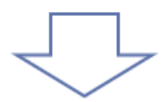

Development of a theory
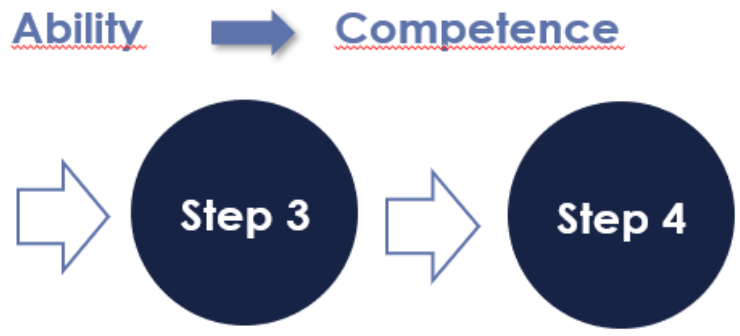

DEDUCE RECORD
Testing

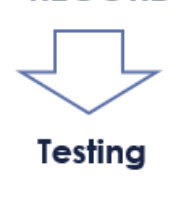

OBSERVE AND

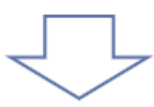

Theory validation and formulation of new rules

Figure 1 - Learning process' stages designed for Buildin \& Learning Project 
After the theoretical phase (step 1), groups built the LEGO's model for the guided experiment, useful to learn the concepts previously exposed. The practical phase (steps 2, $3,4)$ has a guideline tab to report every step of the experiment. After the observation of the model, groups write what they think could happen during the experiment and explain why they speculate that conclusion. Finally, after the experiment, they report the results and explain what happened. If their hypothesis was wrong, they must explain the reasons. The tabs are part of the curricular evaluation.

For data collection, we used quantitative and qualitative methods, to get a complete overview of the situation before, during and after the courses. The quantitative data came from five different standard tests and from the checklists used during the lessons. In particular, we prepared an entering and exiting tests about the social competence and the European skill "learn to learn", while the three intermediate tests monitored the school knowledge, the abilities and competences level in technology topics. Besides, we used a checklist to monitor teacher's kind of questions that could be traditional, deductive or inductive. The first one requires just recalling previous information, the second one requires using past academic knowledge to find a general principle that explains a particular phenomenon, while the last one requires finding a rational explanation using the context resources and previous experience memories. We hypothesized that just the second and the third kind of questions could be useful for the development of competencies. The qualitative data came from the personal camp notes token during the courses, from the open questions of the entering and exiting tests. Lastly, every lesson was audio-recorded to facilitate the data analysis.

To achieve the goals proposed by ONU for a Sustainable Development (Agenda 2030) we selected the curricular subjects connected to the models proposed by LEGO's Education set "Simple \& Powered machines" (Fig. 2).

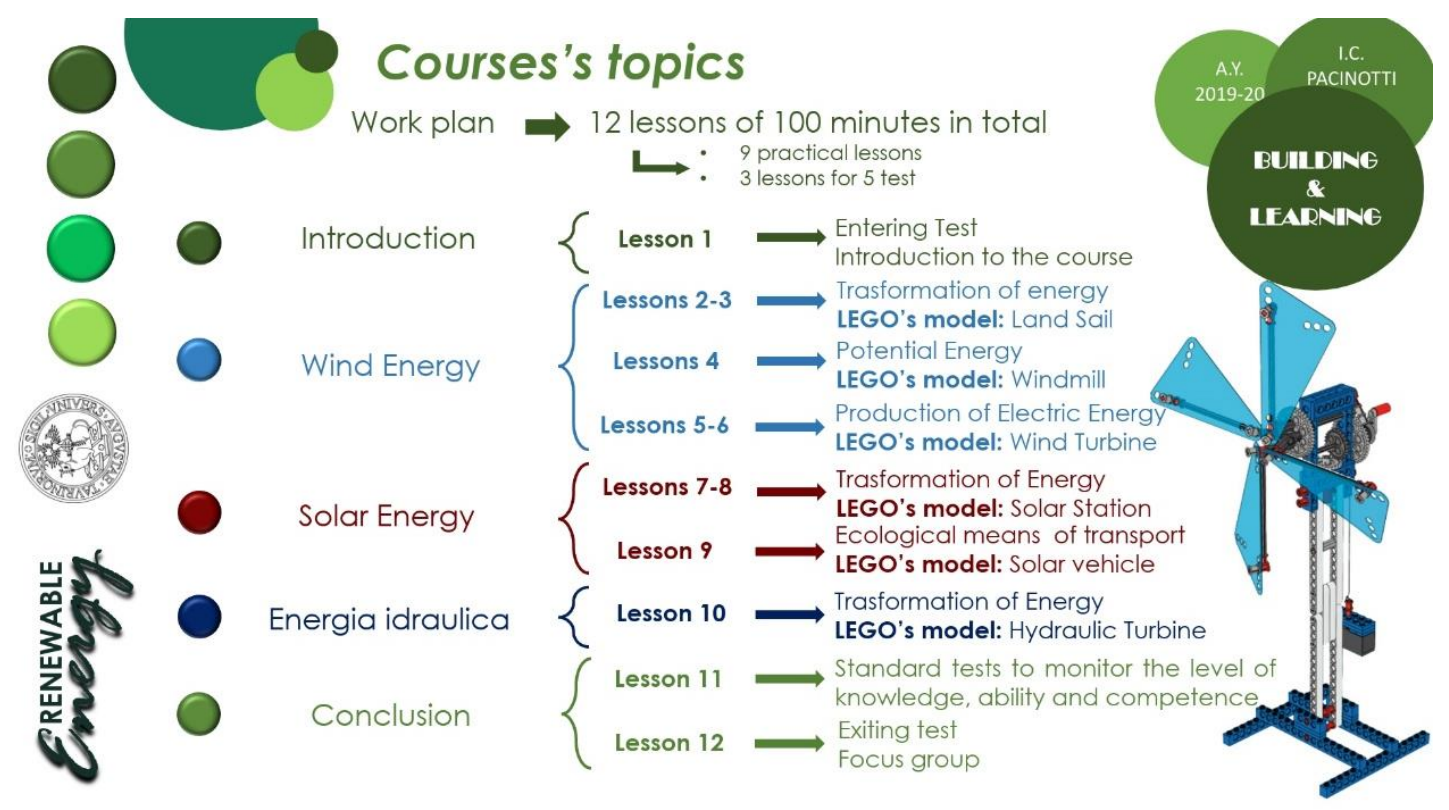

Figure 2 - Examples of Courses' topics 


\section{Results and Conclusions}

Builduing\&Learning is a three years action-research project. In fact, the hosting school I.C. Pacinotti (Turin - Italy) include the project in the POF for 6 classes (2 first grades, 2 seconds, 2 thirds). Vitti is the tenured professor of every participant classes. The researcher decided to collaborate whit Cinedumedia Center for the improvement of teaching method making available her lessons hour. Because of Covid-19 emergency, the project ended before the students of Energy course could perform knowledge, abilities and competences tests and the exiting test. Otherwise, we achieved qualitative and quantitative data whit the entering test and during the project.

The tests showed not just a low level of language competence, but the absence of grammar knowledge connected to the difficulty of understanding the questions. Since lot of students did not speak Italian as first language, we decided to introduce more written storytelling activities using digital instruments. Before tests' analysis we though to propose to the students two types of storytelling activities: digital and not digital. The second one was a daily work: the students must report on a guide tab theirs previsions about the experiment, what happened in every experiment and which rules could we deduce from the experiment. For de digital activities we divided the work in two parts: during every lesson the groups had to record some videos and take photos about their work. At the end of every didactic unit they had to prepare a PowerPoint presentation or a multimedia video. This digital artifact has been valuated as part of Technology curricular vote. After the analysis of the tests the research group decided to propose also some documentaries about renewable energy, asking them to fill a tab writing videos' key word and principal theoretical concepts.

The qualitative and quantitative achieved data about team working competence and civic behaviors show an improvement in this area. Thanks to Cooperative Learning methods, we registered gradually more fluid human interaction and a gradual improvement in team working and in respect other students' opinion (Tab 1). The evaluation is based on the item proposed by Bales (1950, cit. in Kaneklin, 2010) in IPA checklist. All the student received two votes: one individual and one for the group.

Table 1. Groups Evaluation in Renewable Energy courses

\begin{tabular}{|l|l|l|l|}
\hline Class 1 & Class 2 \\
\hline Group & Vote & Group & Vote \\
\hline $\mathbf{1}$ & 8 & $\mathbf{1}$ & 8.5 \\
\hline $\mathbf{2}$ & 8.5 & $\mathbf{2}$ & 8 \\
\hline $\mathbf{3}$ & 8 & $\mathbf{3}$ & 7.5 \\
\hline $\mathbf{4}$ & 8.5 & $\mathbf{4}$ & 8.5 \\
\hline $\mathbf{5}$ & 7 & $\mathbf{5}$ & 8 \\
\hline $\mathbf{6}$ & 8 & $/ /$ & $/ /$ \\
\hline
\end{tabular}

Camp's notes show also that the complexity of LEGO models and the experiment preparation took longer than expected. After the first two practical lessons, ended in both classes lately and without the participation of all the groups to the experiment, we decide to extended the course. Thanks to the documentaries, that we used to introduce 
the topics, we reduced to a minimum the theory part of the lessons. In this way, all the groups had the time to build correctly the models and to try in person to do the experiment, and not only to observe it. Many students of the Renewable Energy course of next year participated for the school year 2019-2020 to a Construction Science course, designed on the same didactic method proposed in this paper. For this reason, we think that during next Energy course we will register less problem connected to the building and the experiment part. In any case, the future courses will have more digital storytelling activities. Since we extended the Renewable Energy course, this classes never took the curricular tests. However, the results registered in other courses designed on the same didactic method (Tab 2) show that it seems work to get knowledge, ability and competence goals in more than $50 \%$ of cases.

Table 2. Results of curricular tests took by Robotic and Construction Science courses

\begin{tabular}{|l|l|l|}
\hline Course & Sufficient Votes & Unsufficient Votes \\
\hline Knowledge & 50 & 23 \\
\hline Ability & 36 & 34 \\
\hline Competence & 47 & 26 \\
\hline
\end{tabular}

About the ability goal (Tab 3), we think that the results obtained in the Robotic course, could be connected to the limited knowledge in Mathematics, Science and Technology. In fact, this test required to the student to applicate not just the exposed theory, but to use STEAM knowledge to solve new problems. After this firs year we decided to move the course from the first four month period to the second. After the second year of research we will see if the change is enough to get the goal also for the younger students.

Table 3. Results of Ability tests took by Robotic and Construction Science courses

\begin{tabular}{|l|l|l|}
\hline Course & Sufficient Votes & Unsufficient Votes \\
\hline Robotic & 11 & 26 \\
\hline Construction Science & 25 & 8 \\
\hline Total & $\mathbf{3 6}$ & $\mathbf{3 4}$ \\
\hline
\end{tabular}

Lastly, next year is going to be the occasion to verify the effectiveness of the courses as part of teachers' training: after a year of observation and participation as supporting tutor, Sacco, who has a disciplinary and a pedagogical academic formation, are going to be the teachers of Robotic courses.

\section{References}

AGENDA 2030 - Sustainable Development Goals (SDGs)

CAMBI F. (2014), Saperi e competenze, La Terza, Bari

CASTOLDI M. (2011), Progettare per competenze. Percorsi e strumenti, Carocci Editore, Roma

CECCHINATO G., PAPA R. (2016), Flipped Classroom un nuovo modo di insegnare e apprendere, De Agostini Scuola, Novara

D'ANGELLA F., ORSENIGO A. (1999), La progettazione sociale, Edizioni Gruppo Abele, Torino

DELORS J. (1996), Nell'educazione un tesoro, Armando Editore, Roma

DEWEY J. (1965), Democrazia e educazione, La Nuova Italia, Firenze 
EATON M. (2017), The flipper Classroom, John Wiley \& Sons Ltd and The Association for the Study of Medical Education, THE CLINICAL TEACHER, $N^{\circ}$ 4, v. 14, pp. 301-302

GUASTI L. (2016), Didattica per competenze. Orientamenti e indicazioni pratiche, Edizioni Centro Studi Erikson, Trento

JOHNSON D.W., JOHNSON R.T., HOLUBEC E.J. (2015), Apprendimento cooperativo in classe. Migliorare il clima emotivo e il rendimento, Edizioni Centro Studi Erikson, Trento

KANEKLIN C. (2010), Il gruppo in teoria e in pratica. L'intersoggettività come forza produttiva, Raffaello Cortina Editore, Milano

KRÖNINGER-JUNGABERLE H., NAGY E., VON HEYDEN M., DUBOIS F. (2015), REBOUND: A media-based life skills and risk education programme, Health Education Journal (HEJ), $\mathrm{N}^{\circ} 6$ v. 74, pp. 705-719

LOSITO B., POZZO G. (2005), La ricerca azione. Una strategia per il cambiamento nella scuola, Carocci Editore, Roma

MACCARIO D. (2012), A scuola di competenze. Verso un nuovo modello didattico, SEI, Torino

MILANI L. (2013), Collettiva-mente. Competenze e pratica per le équipe educative, Società Editrice Internazionale, Torino

OTTOLINI G., RIVOLTELLA C. (2014), Il tunnel e il kayak. Teoria e metodo della peer\&media education, Franco Angeli, Milano

PORCARELLI A. (2016), Progettare per competenze. Basi pedagogiche e strumenti operativi, Diogene Multimedia, Bologna

RANIERI M. (2011) Le insidie dell'ovvio. Tecnologie educative e critica della retorica tecnocentrica, Edizioni ETS, Pisa

REEVES C. (2000), Socially Responsible Educational Technology Research, Educational Technology Publications, Inc., $\mathrm{N}^{\circ}$ 6, v. 40, pp. 19-28

SPENCER L.M., SPENCER S.M. (1995), Competenza nel lavoro. Modelli per una performance superiore, Franco Angeli, Milano

SCARCELLI, C. M. (2017), Telling, Doing, (Media)Educating. Adolescents' Experiences, Expectations, Suggestions Concerning Media Education, Italian Journal of Sociology of Education, $N^{\circ} 9$ v. 1, pp. 93-121.

STARA F. (2014) (a cura di), La costruzione del pensiero e delle strategie interculturali, Pensa MultiMedia Editore, Lecce

TRINCHERO R., Manuale di ricerca educativa, Franco Angeli, Milano, 2002

TRINCHERO R. (2012), Costruire, valutare, certificare competenze. Proposte di attività per la scuola, FrancoAngeli, Milano 